\title{
MESIN PENCETAK STIK BENTUK AKAR KELAPA
}

\author{
Zaldy Kurniawan ${ }^{1}$, Hariyanto ${ }^{2}$, Findra Setyanto ${ }^{3}$, Rapiansah ${ }^{4}$, Zulkipli $^{5}$ \\ Laboratorium Mekanik Jurusan Teknik Mesin \\ Politeknik Manufaktur Negeri Bangka Belitung \\ Kawasan Industri Airkantung, Sungailiat-Bangka, 33211 \\ Telp. 0717 93586, Faks. 071793585 \\ e-mail: zaldy@polman-babel.ac.id
}

\begin{abstract}
Abtract
Besides getas and kemplang, one snack which most people like in Bangka Island isa a snack with the form of a palm tree roots. The craftsmen who manufacture these sticks derived from Pangkalpinang. The results of the survey on the Small Industries (IKM) in the District Gerunggang show that the production process sticks using manual equipment/manpower. To overcome the problems of IKM, hence the researcher designed to facilitate the molding machine in the production process and speed up production so as to produce a better capacity of production by using the manual method. The method used in this research is to design and calculation by using computing devices Solidwork. This stick molding machine uses a mechanism that rotates a threaded shaft, then an emphasis on the dough so that these products can be pushed toward the output. From the experimental results the output of this machine is the root of the stick-shaped palm with a size $100 \times 5 \mathrm{~mm}$, output 500 gram / 5 minutes by the number of \pm 80 -100 grains stick.
\end{abstract}

Keywords: press machine, a threaded shaft, sticks, solidwork.

\begin{abstract}
Abstrak
Selain getas dan kemplang, salah satu makanan ringan yang disukai sebagian masyarakat Pulau Bangka adalah stik bentuk seperti akar pohon kelapa. Adapun pengerajin yang memproduksi stik tersebut berasal dari kota Pangkalpinang. Hasil survei pada Industri Kecil Menengah (IKM) di Kecamatan Gerunggang tersebut menunjukkan bahwa proses produksi stiknya dengan menggunakan peralatan manual/tenaga manusia. Untuk mengatasi permasalahan IKM, maka dirancanglah mesin pencetak yang dapat memudahkan dalam proses produksi dan mempercepat waktu produksi sehingga dapat menghasilkan kapasitas yang lebih baik dari produksi dengan menggunakan cara manual. Metode yang digunakan pada penelitian ini adalah perancangan dan perhitungan dengan menggunakan perangkat komputasi Solidwork. Mesin pencetak stik ini menggunakan mekanisme poros berulir yang berputar, kemudian terjadi penekanan pada adonan sehingga produk tersebut dapat terdorong menuju output. Dari hasil percobaan output dari mesin ini adalah stik berbentuk akar kelapa dengan ukuran 100x5 mm, output 500 gram $/ 5$ menit dengan jumlah stik \pm 80-100 butir stik.
\end{abstract}

Kata kunci : mesin pencetak, poros berulir, stik, solidwork.

\section{PENDAHULUAN}

Era globalisasi saat ini tumbuhnya industri-industri rumahan dalam masyarakat khususnya yang berskala kecil dan menengah perlu terus didukung dalam membangkitkan perekonomian masyarakat. Masyarakat Industri Kecil Menengah (IKM) atau industri rumah tangga diharapkan berperan aktif guna menghasilkan suatu produk yang berkualitas. Oleh karena itu, untuk membuat atau mengembangkan teknologi yang memiliki manfaat dan lebih ekonomis diharapkan dapat mengembangkan inovasi-inovasi produk terbaru. Dengan demikian, inovasi tersebut dapat membantu dalam proses produksi dalam suatu industri rumahan. Salah satu industri rumahan yang memproduksi pembuatan stik bentuk akar kelapa dengan menggunakan peralatan manual dapat ditunjukkan pada Gambar 1.1 berikut: 

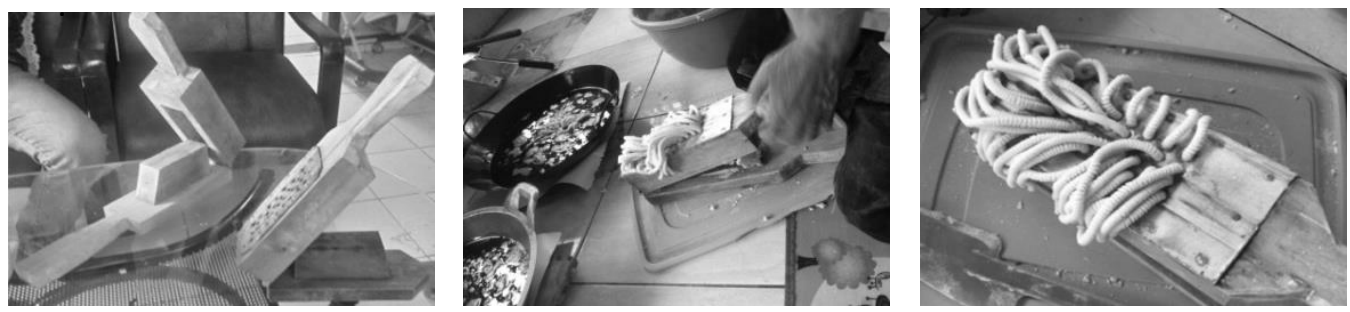

Gambar 1.1 Pembuatan Stik Bentuk Akar Kelapa Dengan Peralatan Manual

IKM AL Faris snack yang ada di kota Pangkalpinang saat ini memproduksi makanan ringan/stik bentuk akar kelapa dengan menggunakan peralatan manual, dengan bantuan alat tersebut pada saat pengoperasiannya harus menggunakan tenaga manusia yang lebih untuk mendapatkan stik bentuk akar kelapa. Demikian pula, salah satu faktor pendorong laris manisnya bisnis makanan ringan/stik ini dipasaran adalah faktor konsumen yang gemar makan camilan.[1]. Dari hasil survei lapangan, untuk mencetak stik bentuk akar kelapa dengan berat adonan 3 (tiga) kg dibutuhkan waktu selama 2 (dua) jam. Dengan demikian, waktu proses produksinya akan menjadi lebih lama karena menggunakan tenaga manusia.

Berkaitan dengan tenaga manusia tersebut, tubuh manusia dirancang untuk dapat melakukan aktivitas pekerjaan sehari-hari. Dengan bekerja berarti tubuh akan menerima beban dari luar tubuh, dengan kata lain bahwa suatu pekerjaan merupakan beban bagi yang bersangkutan. Beban tersebut dapat berupa beban fisik maupun mental. Metode pengukuran langsung yaitu dengan melakukan pengukuran energi yang dikeluarkan (energy expenditure) melalui asupan oksigen selama bekerja. Dengan asumsi semakin berat beban kerja akan semakin banyak energi yang diperlukan atau dikonsumsi[2].

Berdasarkan hal-hal yang telah dijelaskan, maka dilakukan suatu penelitian tentang perancangan mesin pencetak stik yang dapat mengurangi penggunaan tenaga pekerja dan untuk mempercepat waktu proses produksinya. Selain itu, mesin tersebut mampu mencetak stik bentuk akar kelapa dengan kapasitas 4,8 kg untuk proses pencetakan dengan waktu 1 jam.

\section{METODE PENELITIAN}

Adapun metode penelitian yang gunakan dalam penelitian ini akan diuraikan melalui langkahlangkah yang dilakukan untuk menentukan tindakan yang dilakukan. Adapun tahapan-tahapan yang telah dilakukan, dijelaskan pada Gambar diagram alir 2.1 berikut:

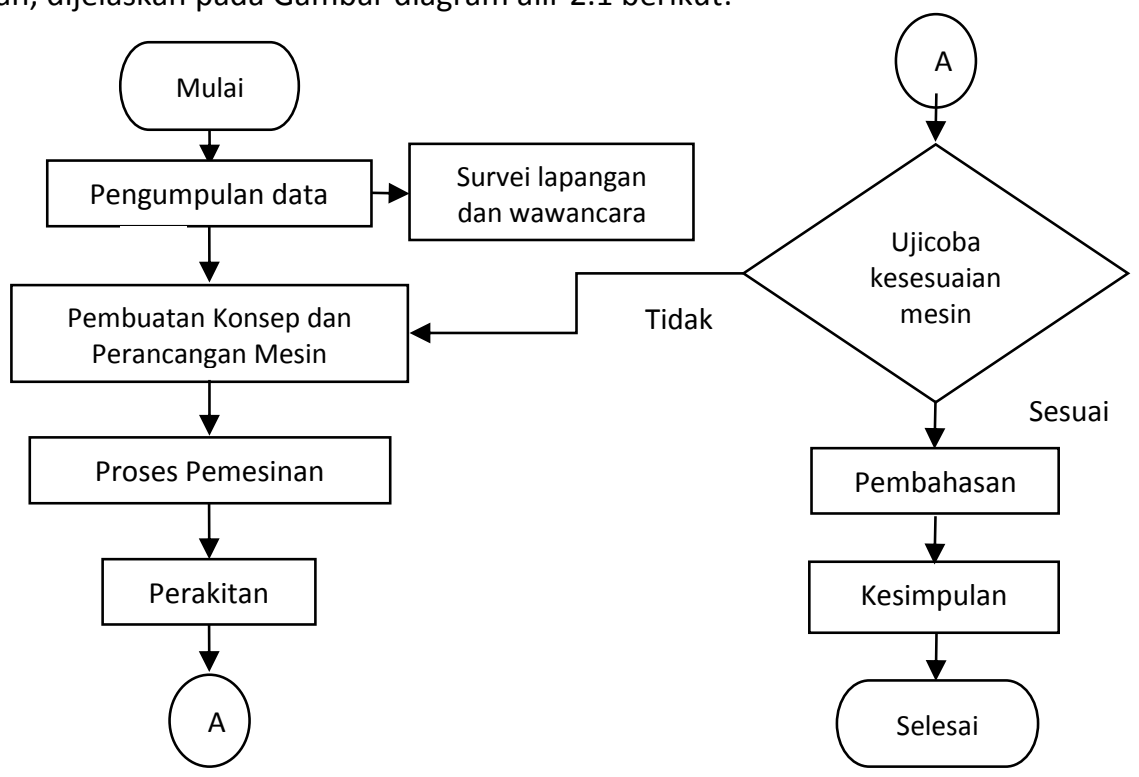

Gambar 2.1 Diagram alir metode penelitian 


\subsection{Metode Pengumpulan Data}

Pengumpulan data dilakukan dengan beberapa melakukan survei lapangan yang bertujuan untuk mendapatkan data-data yang mendukung untuk pembuatan stik bentuk akar kelapa.

\subsection{Pembuatan Konsep dan Perancangan}

Konsep perancangan mesin dilakukan sesuai dengan data-data yang diperoleh saat melakukan pengumpulan data yang dituangkan berupa ide dalam bentuk konsep gambar. Perancangan mesin dilakukan dengan melihat kebutuhan mesin yang ada di masyarakat. Kemudian perancangan tersebut ditrasnformasi menjadi konsep rancangan [3], dengan luarannya berupa pemilihan alternatif rancangan yang dihitung sesuai dengan analisis rancangannnya. Dengan demikian, nantinya akan terpilih salah satu alternatif rancangan yang berdasarkan target yang ingin dicapai.

\subsection{Proses Pemesinan, Perakitan dan Percobaan Alat}

- Proses Pemesinan

Hasil tahapan perancangan berdasarkan rancangan yang telah dihitung, sehingga mempunyai arah yang jelas pada saat pembuatannya, dari gambar kerja tersebut yang luarannya adalah langkahlangkah pembuatan komponen mesin yang akan dibuat melalui proses pemesinan pada mesin perkakas[4].

\section{- Perakitan}

Tahapan ini, proses perakitan yang dilakukan dengan dengan cara menggabungkan komponenkomponen yang telah dibuat, sehingga menjadi suatu alat atau mesin.

Proses perakitan dilakukan setelah melakukan tahapan pembuatan bagian komponen-komponen mesin tersebut. Dengan demikian, alat ataupun komponen yang dibuat dapat dirakit sesuai fungsi/gambar yang dirancang.

\section{- Ujicoba Alat}

Setelah mesin dinyatakan selesai dirakit, maka tahapan selanjutnya melakukan ujicoba, untuk mengetahui kinerja mesin yang selesai dirakit. Percobaan ini dilakukan dengan mengetahui fungsi sistem kerja dari alat tersebut. Jika percobaan tidak sesuai dengan yang diinginkan maka proses selanjutnya adalah perbaikan pada sistem yang mengalami gangguan tersebut. Ujicoba dijadikan sebagai acuan untuk mengukur berhasil atau tidaknya alat yang dibuat, sehingga dapat dievaluasi tingkat keberhasilan mesin yang dibuat.

\section{HASIL DAN PEMBAHASAN}

\subsection{Daftar Tuntutan}

Selanjutnya perancangan alat stik bentuk akar kelapa diawali dengan membuat daftar tuntutan yang diinginkan dari peralatan dan ditunjukkan pada Tabel 3.1 berikut ini:

Tabel 3.1 Daftar Tuntutan Mesin Pencetak Stik Bentuk Akar Kelapa

\begin{tabular}{|c|c|c|}
\hline No & Daftar Tuntutan & Deskripsi \\
\hline 1 & $\begin{array}{l}\text { Tuntutan Utama } \\
\text { - } \quad \text { Alignment puli dan belt } \\
\text { - } \quad \text { Stik bentuk akar kelapa }\end{array}$ & $\begin{array}{l}\text { - Kesejajaran dan kesikuan } \\
\text { - Luarannya produk seperti bentuk } \\
\text { akar kelapa }\end{array}$ \\
\hline 2 & $\begin{array}{l}\text { Tuntutan Kedua } \\
\text { - Luaran } \\
\text { - Konstruksi mesin }\end{array}$ & $\begin{array}{l}\text { - Stik berbentuk akar kelapa yang } \\
\text { homogen } \\
\text { - Tangguh }\end{array}$ \\
\hline 3 & $\begin{array}{l}\text { Keinginan } \\
\text { - } \quad \text { Pengoperasian } \\
\text { - } \quad \text { Rangka } \\
\text { - } \quad \text { Perawatan }\end{array}$ & $\begin{array}{l}\text { - Aman dan mudah } \\
\text { - Sederhana } \\
\text { - Mudah }\end{array}$ \\
\hline
\end{tabular}




\subsection{Alternatif Fungsi Bagian}

a. Fungsi Elemen Transmisi

Alternatif fungsi elemen transmisi dengan menggunakan puli dan sabuk yang digunakan untuk alat yang akan dibuat. Output dari elemen transmisi tersebut adalah putaran. Alternatif ini dipilih karena puli dan sabuk tidak berisik dan mudah dalam perawatan.

\section{b. Fungsi Sistem Pencetak}

Adapun sistem pencetak dalam rancang bangun mesin pencetak stik bentuk akar kelapa dengan menggunakan sistem ulir. Sistem ini mudah saat pengerjaan pada proses pemesinan dan perakitan, serta mudah saat proses dibongkar pasang.

\section{c. Fungsi Rangka}

Sistem rangka fix yang digunakan dalam rancang bangun mesin pencetak stik ini dengan menggunakan sistem las dengan menggunakan material plat siku L 40x40mm.

\section{d. Fungsi Penggerak}

Sistem penggerak dalam rancang bangun mesin pencetak stik bentuk akar kelapa dengan menggunakan motor listrik $1 / 2$ PK sebagai penggerak utamanya.

\subsection{Variansi Konsep}

Dengan menggunakan metoda kotak morfologi, alternatif-alternatif fungsi bagian dikombinasikan menjadi alternatif fungsi keseluruhan, [5] yang ditunjukkan pada Tabel3.2 berikut:

Tabel 3.2 Tabel Penilaian Alternatif Mesin Pencetak Stik Bentuk Akar Kelapa

\begin{tabular}{|c|c|c|c|}
\hline \multirow{2}{*}{ No } & \multirow{2}{*}{ Fungsi Bagian } & \multicolumn{2}{|c|}{ Variasi Konsep ( VK ) } \\
\hline & & AF 1 & AF 2 \\
\hline 1 & Fungsi Tranmisi & & $A-2$ \\
\hline 2 & Fungsi Pencetak & $B-1$ & \\
\hline 3 & Fungsi Rangka & & $C-2$ \\
\hline \multirow[t]{2}{*}{4} & Fungsi Penggerak & $D-1$ & $D-2$ \\
\hline & $\begin{array}{l}\text { Hasil Variansi Konsep } \\
\text { ( VK) }\end{array}$ & VK 1 & VK 2 \\
\hline
\end{tabular}

\subsection{Keputusan}

Setelah dilakukan proses pemilihan alternatif maka keputusan akhir terpilih variansi konsep (VK 1) untuk pembuatan mesin stik bentuk akar kelapa ditunjukkan seperti pada Gambar 3.1 Sedangkan hasil rancang bangun pembuatan mesin yang sesuai dengan rancangan dapat dilihat pada Gambar 3.2 berikut:
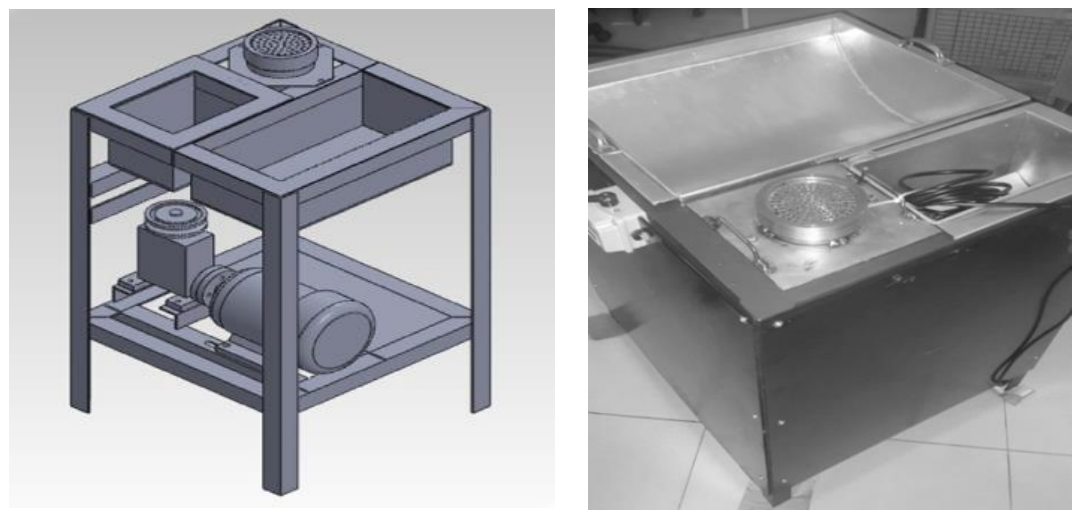

Gambar 3.1 Alternatif rancangan terpilih

Gambar 3.2 Mesin pencetak stik bentuk akar kelapa 


\subsection{Ujicoba}

Data hasil ujicoba mesin pencetak stik bentuk akar kelapa dilakukan beberapa kali ujicoba, untuk memperoleh hasil pencetakan yang baik dan maksimal dan ditunjukkan pada Tabel3.3 berikut:

Tabel 3.3 Hasil ujicoba mesin pencetak stik bentuk akar kelapa

\begin{tabular}{|c|c|c|c|c|c|}
\hline $\begin{array}{l}\text { Ujico } \\
\text { ba }\end{array}$ & Tanggal & Uraian & Hasil & Waktu & Ket. \\
\hline 1 & 19 Juli 2016 & $\begin{array}{l}\text { Adonan stik } \\
\text { dimasukkan }\end{array}$ & 400 gram & 5 menit & $\begin{array}{l}\text { Stik belum sepenuhnya } \\
\text { berbentuk seperti yang }\end{array}$ \\
\hline 2 & 20 Juli 2016 & $\begin{array}{l}\text { sebanyak 0,5 kg } \\
\text { Adonan stik }\end{array}$ & 400 gram & $\begin{array}{l}5 \\
\text { menit }\end{array}$ & $\begin{array}{l}\text { diinginkan } \\
\text { Stik sudah terbentuk dan }\end{array}$ \\
\hline 3 & 21 Juli 2016 & $\begin{array}{l}\text { dimasukkan } \\
\text { sebanyak 0,5 kg }\end{array}$ & 800 gram & 10 & $\begin{array}{l}\text { hasilnya masih terputus- } \\
\text { putus }\end{array}$ \\
\hline 4 & 26 Juli 2016 & $\begin{array}{l}\text { Adonan stik } \\
\text { dimasukkan }\end{array}$ & 800 gram & menit & $\begin{array}{l}\text { Stik sudah terbentuk dan } \\
\text { hasilnya masih terputus- }\end{array}$ \\
\hline 5 & 27 Juli 2016 & sebanyak $1 \mathrm{~kg}$ & 1800 & 10 & putus \\
\hline 6 & 28 Juli 2016 & $\begin{array}{l}\text { Adonan stık } \\
\text { dimasukkan } \\
\text { sebanyak } 1 \mathrm{~kg}\end{array}$ & $\begin{array}{l}\text { gram } \\
1800\end{array}$ & menit & $\begin{array}{l}\text { Stik sudah berbentuk akar } \\
\text { kelapa seperti yang } \\
\text { diinginkan }\end{array}$ \\
\hline 7 & $\begin{array}{l}03 \text { Agustus } \\
2016\end{array}$ & $\begin{array}{l}\text { Adonan stik } \\
\text { dimasukkan }\end{array}$ & gram & menit & $\begin{array}{l}\text { Stik sudah berbentuk akar } \\
\text { kelapa seperti yang }\end{array}$ \\
\hline 8 & 04 Agustus & $\begin{array}{l}\text { sebanyak } 2 \mathrm{~kg} \\
\text { Adonan stik }\end{array}$ & $\begin{array}{l}2800 \\
\text { gram }\end{array}$ & $\begin{array}{l}25 \\
\text { menit }\end{array}$ & $\begin{array}{l}\text { diinginkan } \\
\text { Stik sudah berbentuk akar }\end{array}$ \\
\hline \multirow[t]{5}{*}{9} & 2016 & $\begin{array}{l}\text { dimasukkan } \\
\text { sebanyak } 2 \text { kg }\end{array}$ & 2800 & 35 & kelapa \\
\hline & $\begin{array}{l}05 \text { Agustus } \\
2016\end{array}$ & $\begin{array}{l}\text { Adonan stik } \\
\text { dimasukkan }\end{array}$ & gram & menit & $\begin{array}{l}\text { Stik sudah berbentuk akar } \\
\text { kelapa }\end{array}$ \\
\hline & & sebanyak 3 kg & 4600 & 35 & \\
\hline & & $\begin{array}{l}\text { Adonan stik } \\
\text { dimasukkan }\end{array}$ & gram & menit & $\begin{array}{l}\text { Stik sudah berbentuk akar } \\
\text { kelapa }\end{array}$ \\
\hline & & $\begin{array}{l}\text { sebanyak } 3 \mathrm{~kg} \\
\text { Adonan stik } \\
\text { dimasukkan } \\
\text { sebanyak 4,8 kg }\end{array}$ & & $\begin{array}{l}59,5 \\
\text { menit }\end{array}$ & $\begin{array}{l}\text { Stik sudah berbentuk akar } \\
\text { kelapa }\end{array}$ \\
\hline
\end{tabular}

\section{SIMPULAN}

Dari hasil ujicoba mesin dapat ditarik kesimpulan sebagai berikut:

1. Hasil ujicoba menunjukkan sistem pencetak menggunakan sistem ulir, dengan penekanan adonannya menggunakan plat penekan yang bergerak ke arah sumbu vertikal (berlawanan arah gaya gravitasi/bergerak dari bawah keatas). Akan tetapi, untuk memudahkan pergerakan ke sumbu vertikal tersebut, maka ditambahkan 1(satu) sensor dibagian atas dan satu sensor dibagian bawah ulir sehingga pergerakan ulir dapat bergerak secara otomatis.

2. Hasil ujicoba menunjukkan bahwa adanya peningkatan waktu produksi pencetakan stik, dengan banyaknya adonan seberat 4,8 kg dan waktu yang dibutuhkan selama 1 jam.

\section{DAFTAR PUSTAKA}

[1]. Suryajaya," Bisnis Makanan Ringan/Camilan", Teropong Usaha, Wirausaha, 2013.

[2]. Tarwaka, Solichul HA Bakri, Lilis Sudiajeng,"Ergonomi untuk Keselamatan Kesehatan Kerja dan Produktifitas", Uniba Press, Surakarta 2004.

[3]. Harsokoesoemo, Darmawan, "Pengantar Perancangan Teknik", ITB, Bandung 2004.

[4]. Widarto, dkk," Teknik Pemesinan", Direktorat Pembinaan Sekolah Menengah Kejuruan, Departemen Jakarta Pendidikan Nasional 2008:

[5]. Sularso, "Dasar Perencanaan dan Pemilihan Elemen Mesin”, Pradnya Paramita, Jakarta, 2004. 